\title{
Influence of Boiling Water Treatment on Surface Roughness and Surface Microstructure of Set Gypsum (Dental Stone)
}

Tadashi ONIZUKA, Noriko KAMIMURA, Hirotada KAJIWARA, Atsuo NAKASHIMA, Kenichi SUENAGA and Tadashi JIMI

The First Department of Prosthetic Dentistry, Kagoshima University Dental School

8-35-1, Sakuragaoka, Kagoshima 890, Japan

Received July 25, 1995/Accepted October 27, 1995

The influence of boiling water treatment on the surface roughness and surface microstructure of set gypsums was investigated. Typical surfaces before and after immersion in boiling water were compared by means of SEM observation, the Knoop hardness test, and a surface roughness test. The surfaces of set gypsums were rougher than that of an acrylic resin plate, and after immersion in boiling water, highly roughened surfaces and thinner crystal bodies were observed on each specimen under SEM. The knoop hardness of set gypsums was considerably lowered after boiling water immersion. That of die stones was the same or lower than set dental stones. The results showed that even brief immersion in boiling water had profound effects on the dental stone cast, resulting in rougher surfaces and lower hardnesses of set gypsums.

Key words: Set gypsum, Surface roughness, Boiling water treatment

\section{INTRODUCTION}

In the practice of crown and bridge casting, accuracy on the order of microns is required due to the rapid progress of precision casting technology and development of the theory of occlusion. Such precise accuracy concerns steps ranging from taking the impression to polishing the finished work. Surface accuracy of set gypsum, one of major dental cast materials, has been discussed from the standpoints of its compatibility with impression materials and its reproduction of the details of the dental cast. However, surface roughness and hardness of set gypsum, which decide its surface accuracy, are often experienced when boxing wax around the set gypsum is washed out with boiling water in the production of working casts. These phenomena were reported after stone models were immersed in distilled water ${ }^{1,2)}$ boiling water ${ }^{3}$, and exposed to tapwater ${ }^{4}$. However, the mechanism of the degradation caused by water or heat has not been demonstrated.

Here, changes of the set gypsuns were studied before and after immersion in boiling water by determining the surface roughness and Knoop hardness and observing the surface microstructure with scanning electron microscopy (SEM) to verify the heat degradation and find its causes.

\section{MATERIALS AND METHODS}

\section{Fabrication of specimens}

The gypsum materials listed in Table 1 were four die stones (TYPE IV) and one dental stone 
(TYPE III), and were mixed mechanically according to the manufacturer's instructions. Mixed dental stones were placed in acryric resin molds. The molds were $4 \times 4 \times 0.5 \mathrm{~cm}$ for surface roughness testing and SEM observation, and $\phi 2 \times 3 \mathrm{~cm}$ for the Knoop hardness test. After 1 hour, specimens were removed from their molds and were dried in a desiccator with silicagel at room temperature for 24 hours. Specimens for the boiling water test were suspended in boiling water for 5 minutes. After immersion in boiling water, some specimens were immediately dried at room temperature for 48 hours and other specimens were rinsed with distilled water, then dried. Measurements of Knoop hardness should have been made on the surface of each speacimen. However, the surfaces became too rough to make measurements. These surfaces had to be polished to a depth of about $0.2 \mathrm{~mm}$ before measurement.

\section{Measuring conditions}

1) Measurement of the surface roughness

The surface roughness was measured at a measuring load of $0.07 \mathrm{gf}$ and measuring length of $0.8 \mathrm{~mm}$, and magnifications of $2000 \times$ with 10 points average roughness $(\mathrm{Rz})$, using a surface roughness testing instrument*.

2) Measurement of the Knoop hardness

The Knoop hardness was measured at a load of $25 \mathrm{gf}$ and loading time of $10 \mathrm{sec}$, and magunification of $400 \times$, using a Vickers hardness tester**.

3) Statistical analysis

Two types of dental stone samples (FR, SS, MR, SP and PS) were prepared; the control was an acrylic resin plate and determinations were made at 5 random positions on each specimen to obtain a measure of central tendency of mean values for the student $T$ test.

4) Observation of the surface microstructure (SEM)

The samples were coated with golder ions\#, and SEM micrographs were taken at magnifications of $100-3000 \times$ at a $15 \mathrm{KV}$ Acc. voltage ${ }^{\# \text {. }}$

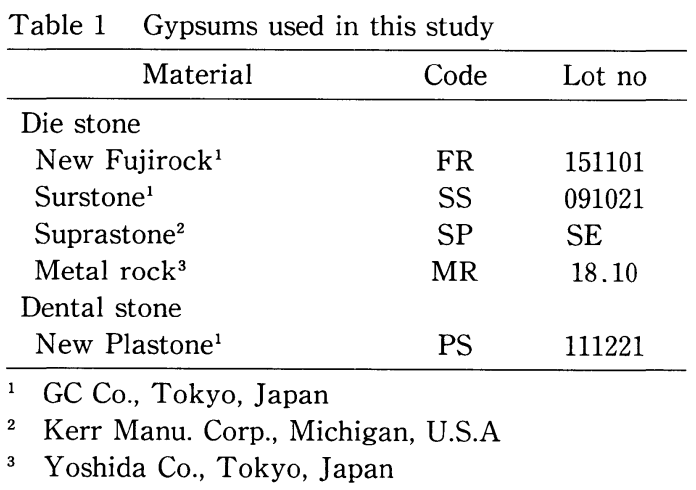

* SURFCOM-700A, Tokyo Seimitu Co., Tokyo, Japan

** MVK-E Vickers hardness tester, Akasi Ltd., Yokohama, Japan

\# FINE COAT JFC-1100, JEOL Ltd., Tokyo, Japan

\# JSM-35CF, JEOL Ltd., Tokyo, Japan 


\section{RESULTS}

Surface roughness of set gypsum

Table 2 shows the change of surface roughness of set gypsums before and after immersion in boiling water. Fig. 1 shows the results of the determinations. Surface roughnesses of test specimens were compared with those of the acrylic resin plate control. Untreated test specimens showed greater roughness than the control. After immersion, increases in roughness were observed in all the test specimens. The SS specimen showed the greatest increase

Table 2 Influence of boiling water treatment on surface roughness of set gypsum

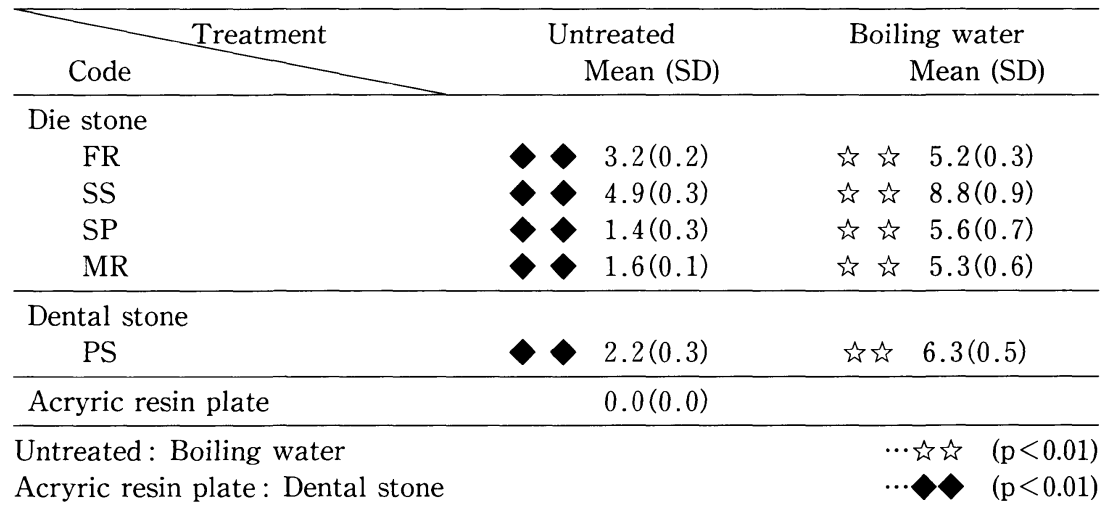

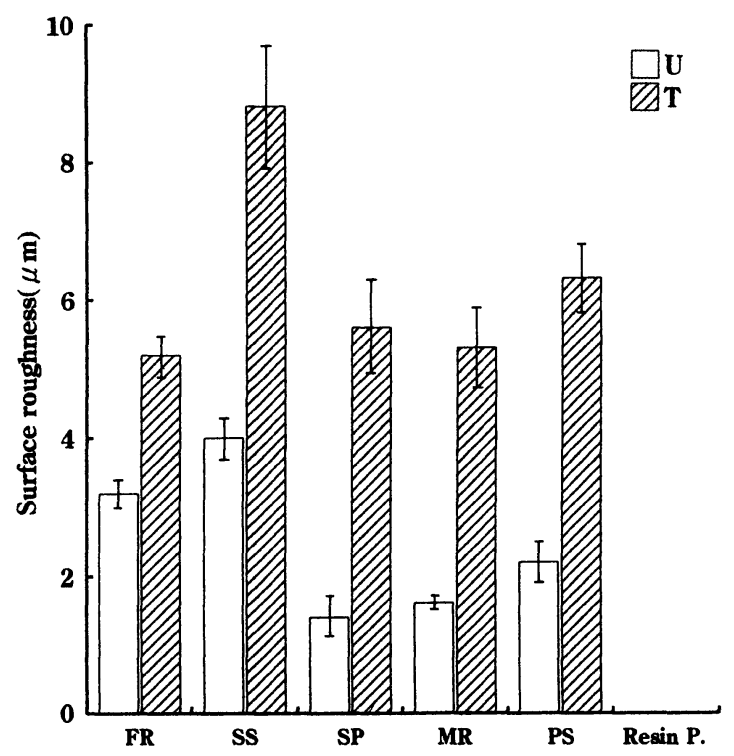

$\mathrm{U}$ : Untreated, $\mathrm{T}$ : Treated with boiling water

Fig. 1 Surface roughness of set gypsum. 
with a post-treatment mean roughness of $8.8 \mu \mathrm{m}$.

Knoop hardness on the surface of set gypsums

The Knoop hardness measurements are shown in Table 3 and Fig. 2. A remarkable fall in Knoop hardness was found after imersion in all test specimens. The hardness of set dental stone before immersion was compared with those of set die stones after boiling water treatment. As the hardness of set die stones decreased, except for FR specimen, the others too showed reductions in hardness. The SP specimen showed a similar hardness to that of the untreated dental stone specimen, and the SS and MR specimens showed lower hardnesses than the untreated set dental stone. These results suggest that set die stone did not retain

Table 3 Influence of the boiling water treatment on Knoop hardness of surface-layers of set gypsum

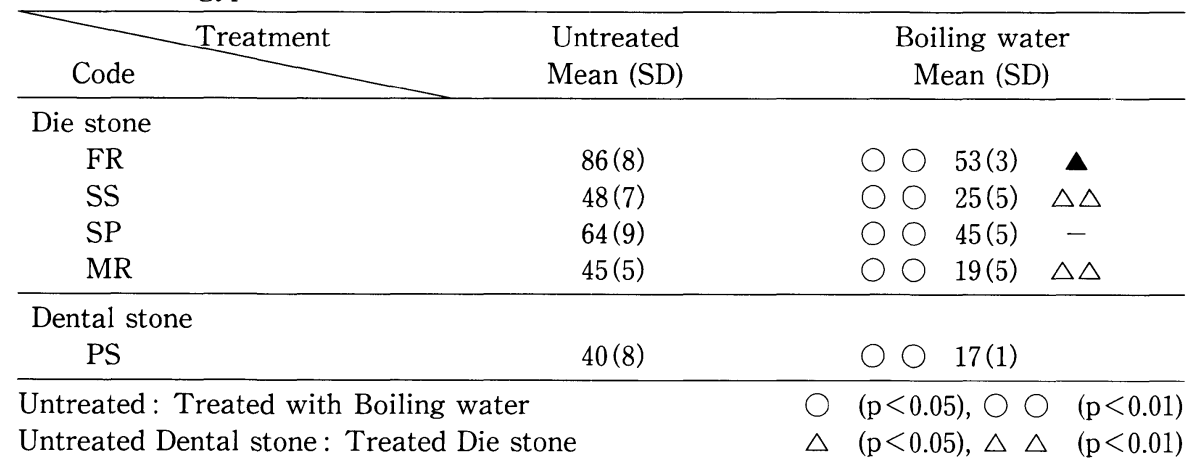

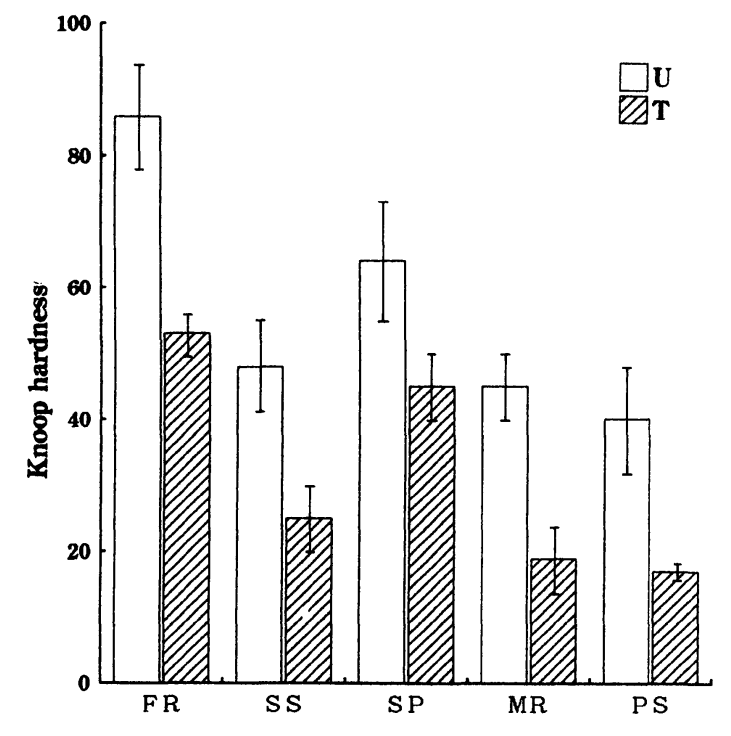

$\mathrm{U}$ : Untreated, $\mathrm{T}$ : Treated with boiling water

Fig. 2 Knoop hardness of set gypsum. 
its essential physical strength after immersion in boiling water.

\section{Observation of surface microstrctures of set gypsums}

Microstructures were observed with SEM to find morphological changes of set gypsums before and after immersion in boiling water. Fig. 3 shows SEM images of the hemihydrate crystals of SP and SS. Fig. 4 shows the morphological changes of the crystals remaining on the surface of SP and SS specimens immersed in boiling water and immediately dried without rinsing. Fig. 3-1 shows plismlike crystals of the hydrocal type usually found in dental stone. Fig. 4-1 shows the surface of the SP specimen after treatment with boiling water. Dissolution of the surface caused the release and damage of hydrocal crystals. They were in stockade along the longitudinal direction, and a perpendicular lack of crystals was also
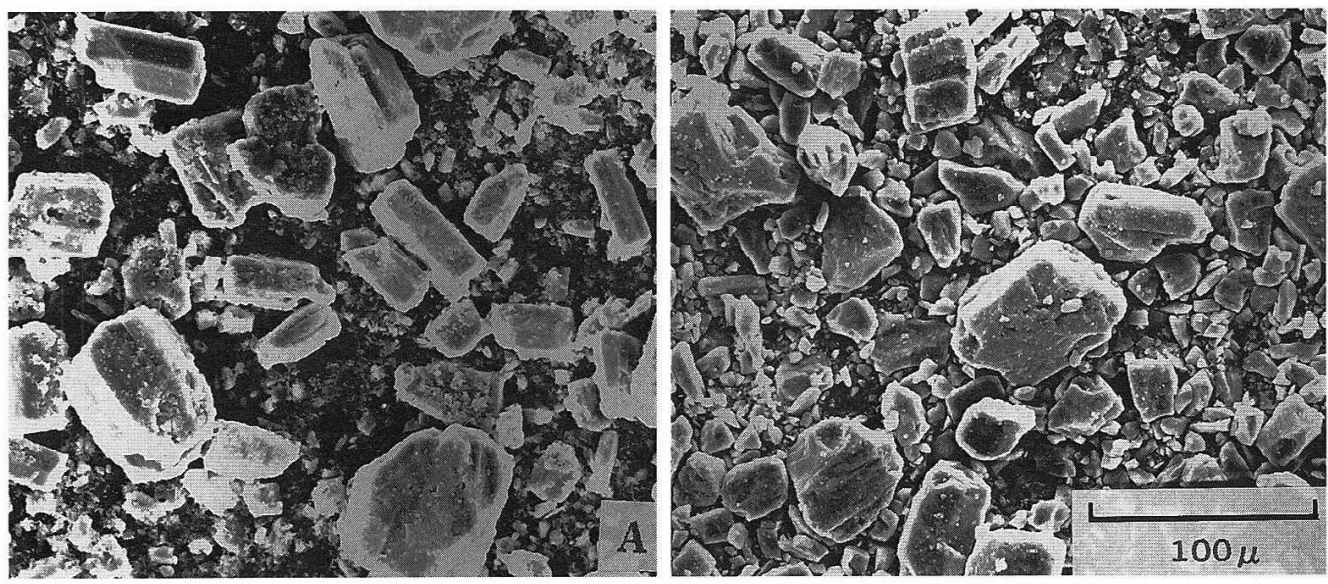

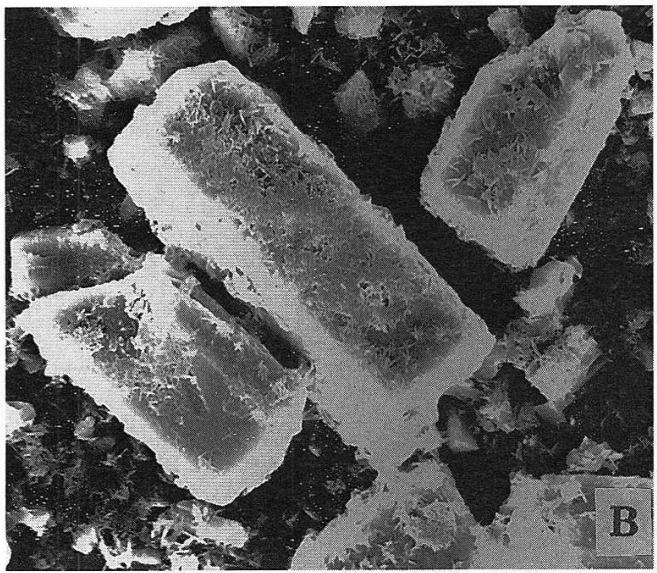

1. Crystals of hydrocal type (SP)

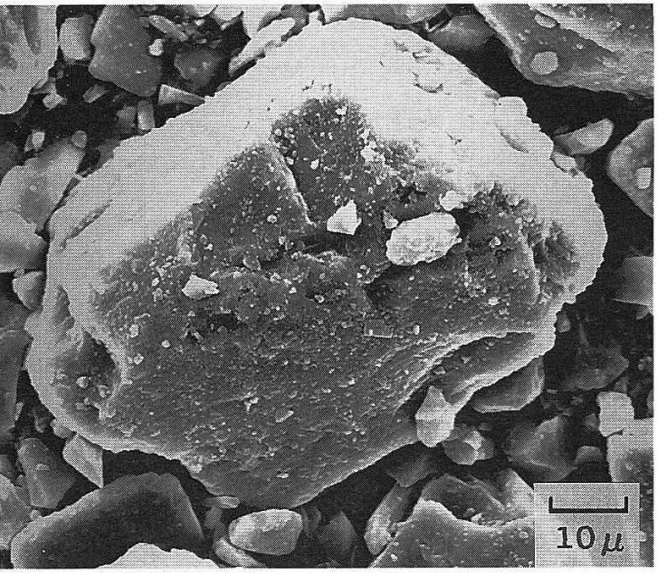

2. Crystals of densyte type (SS) A : $\times 300, B: \times 1000$

Fig. 3 SEM observation of typical hemihydrate crystals. 
observed. Fig. 3-2 shows crystals of SS powder, dental stone of a densite type, often found in die stone. The effects of boiling water treatment on the SS specimen are shown in Fig. 4-2. Crystals released on the surface of the specimen showed plismlike stratiform of minute particles, which was attributed to the dissolution of the crystals in the longitudinal direction. Figs. 5-8 show comparisons of microstructures of various gypsum specimens before and after treatment with boiling water. Fig. 5-1 shows the surfaces of the FR specimen before and after treatment. On the surface of the untreated specimen, crystals with a dihydrate forming board-like shape could be found. They were the widest crystals seen in any of the specimens, extending along the acrylic resin plate which inhibited their growth. Large interspaces was also recognized in the grain boundaries of the crystals. On the surface of the specimen after treatment, shown in Fig. 5-2, profiles of crystals with dihydrate were more


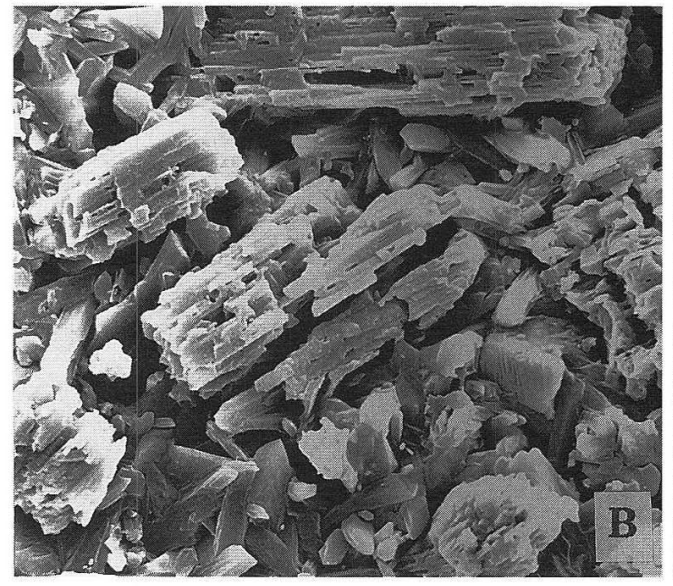

1. Crystals of hydrocal type (SP)

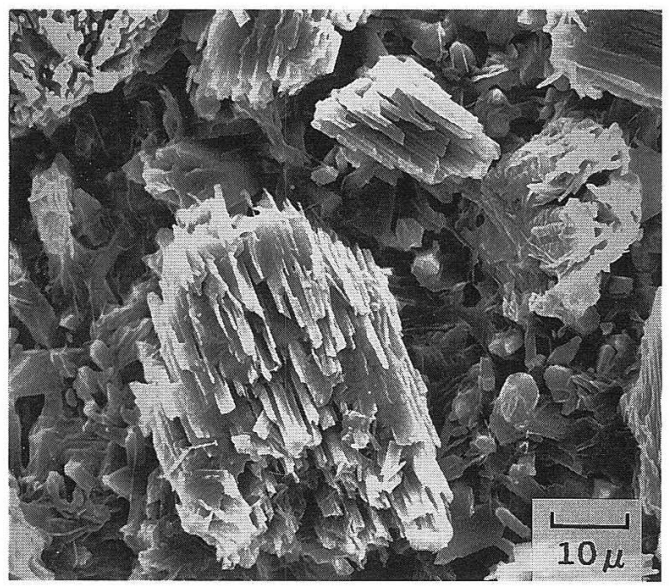

2. Crystals of densyte type (SS) A : $\times 300, B: \times 1000$

Fig. 4 SEM observation of hemihydrate crystals after treatment with boiling water. 
clearly observed and they protruded to the surface to form a larger interspaces in the grain boundaries. Fig. 6-1 shows the surface of SS before treatment, and Fig. 6-2 after treatment. On the former surface small crystals aggregated to form a rough surface with partial cohesion. Fig. 6-2 shows that crystals were dissolved and that innumerable bundles of needlelike crystals remained on the surface. These supported the results of the determination of surface roughness. Figs. 7-1 and 2 show the surface of the MR specimen before and after immersion in boiling water. On the untreated MR surface, crystals with dihydrate were narrower than those on the untreated FR specimen and many pressed needlelike

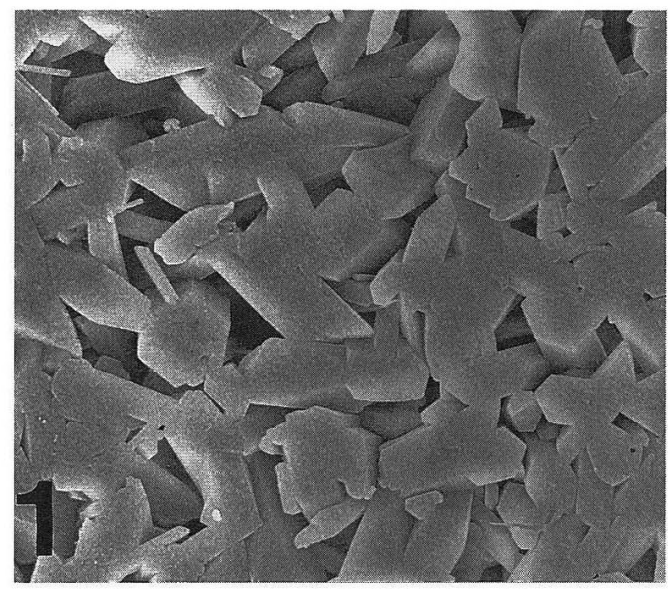

Before

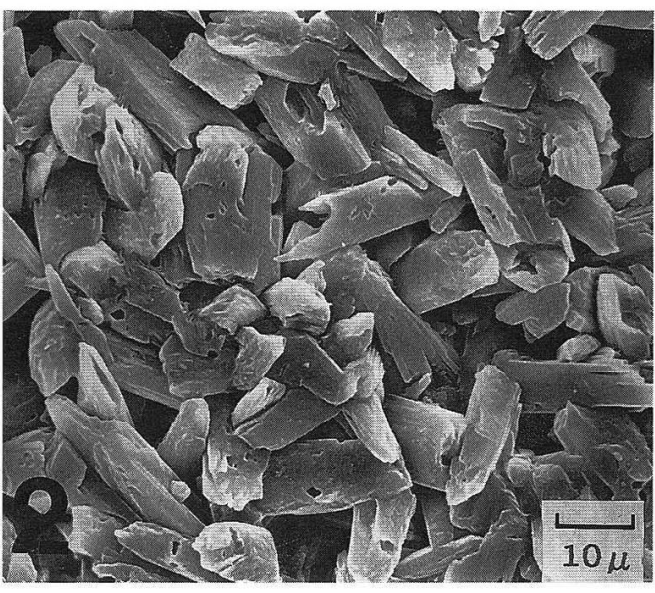

After

Fig. 5 SEM observation of set FR specimen before and after treatment with boiling water.

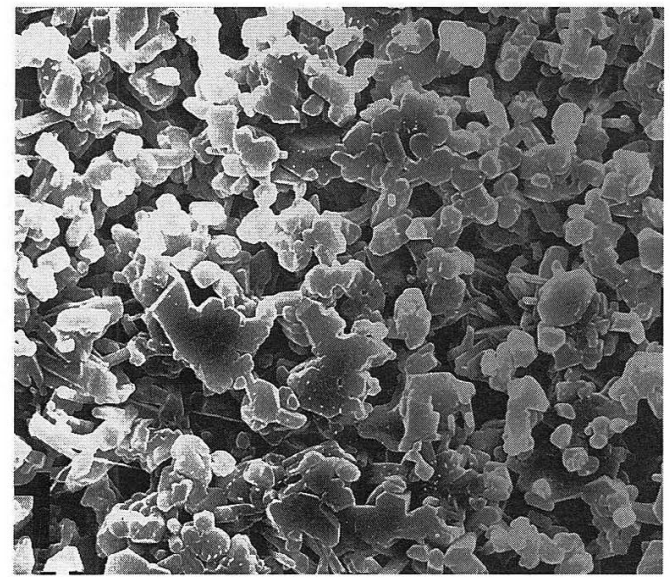

Before

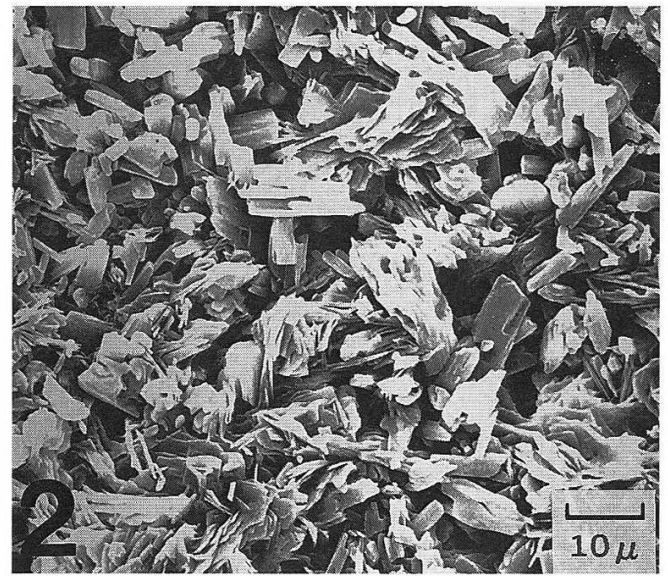

After

Fig. 6 SEM observation of the surface of set SS specimen before and after treatment with boiling water. 
crystals could be recognized. Interspaces in the grain boundaries were reduced. After treatment, the profiles of the crystals with dihydrate became less distinguishable with collapse disruption and cohesion on the surface. These results coincided with the remarkable decrease of Knoop hardness after treatment. Fig. 8 shows the SP specimen before and after treatment. The untreated surface in Fig. 8-1 shows the intermediate picture between those of SF and MR specimen, while Fig. 8-2 shows narrower interspaces than FR but more obvious profiles than MR. Fig. 9 shows the PS specimen, dental stone, before and after treatment. Fig. 9-1 shows needlelike crystals uniformly pressed and cohering to each other,

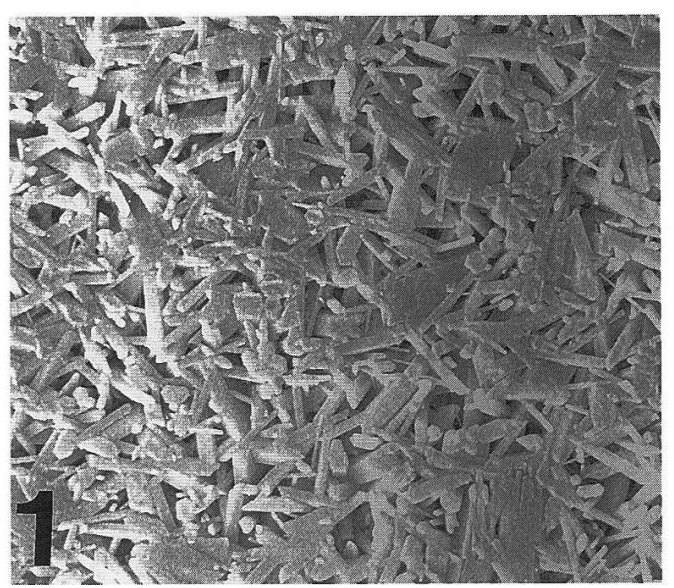

Before

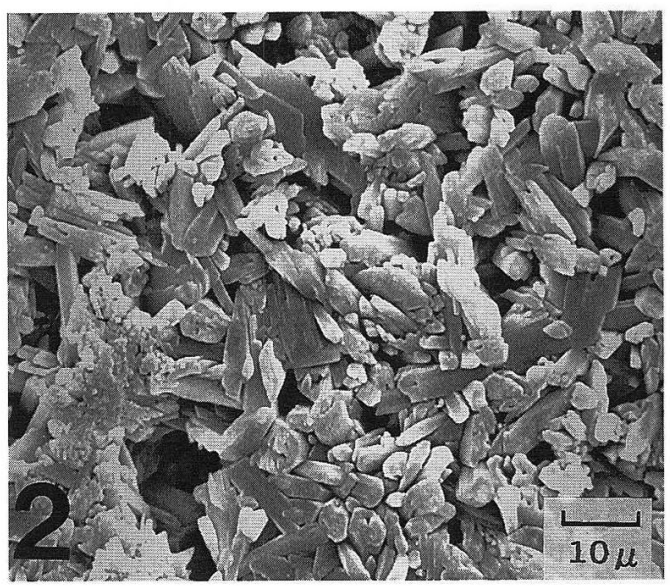

After

$\times 1000$

Fig. 7 SEM observation of the surface of set MR specimen before and after treatment with boiling water.

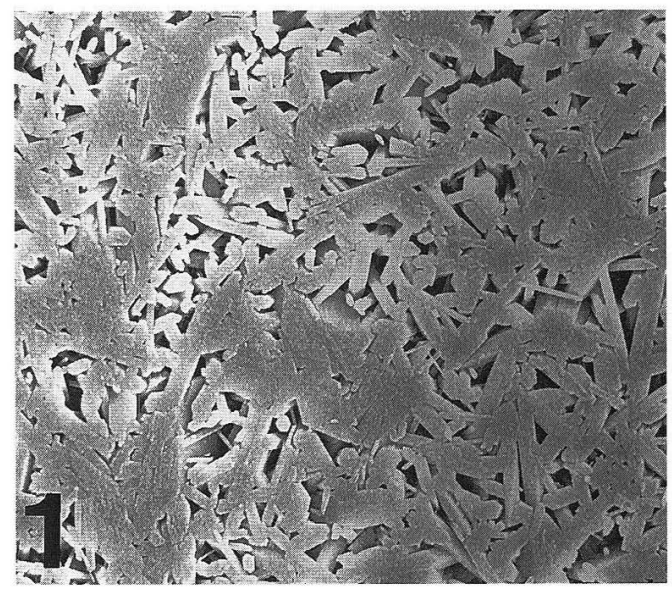

Before



After

Fig. 8 SEM observation of the surface of set SP specimen before and after treatment with boiling water. 


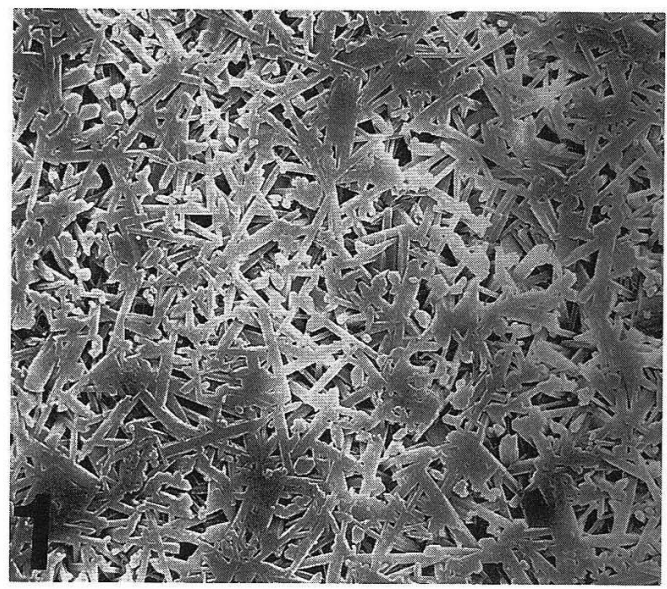

Before

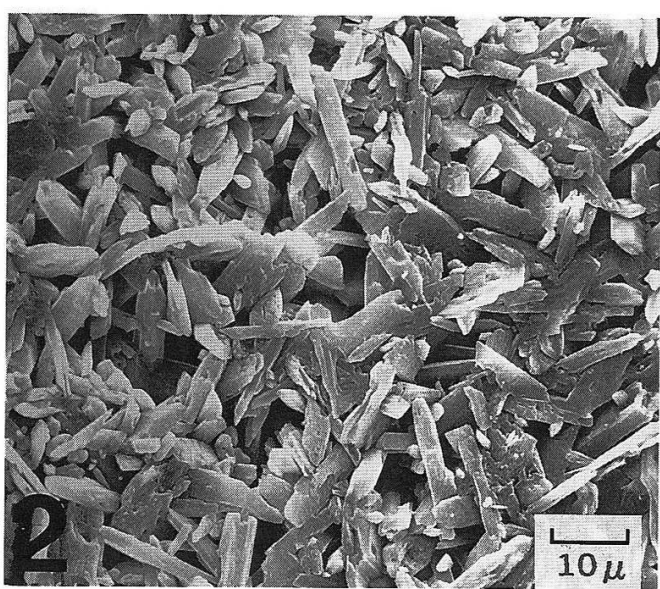

After

$\times 1000$

Fig. 9 SEM observation of the surface of set PS specimen before and after treatment with boiling water.

with fine interspaces observed among them. The pictures of the PS specimen after treatment, on the other hand, are very similar to that of the SP specimen.

\section{DISCUSSION}

Suenaga ${ }^{1)}$, Nakamura ${ }^{5)}$ and Unemori ${ }^{6)}$ determined surface roughness of set dental stone in contact with a plate and obtained values of $1.0 \mu \mathrm{m}$ or less, which differs considerably from our determinations. This difference might be due to the fact that our results were based on average roughness at ten points, average roughness, while theirs were based on center-line average roughness. We observed that the crystals of set dental stone grew along the surface in contact with the plate and that the pressed crystals did not cohere completely, resulting in innumerable pores. These observations led to a hypothesis that our results might be attributed to the presence of interspaces between crystals.

Many researchers have studied the surface hardness of set dental stone. Skinner reported that a thin shell layer of low hardness was formed on the surface of agar impressions and alginate impressions ${ }^{7}$. Mori et al. reported that differences in loading condition caused variation in Knoop hardness and attributed this to the different properties of the outer and inner layers ${ }^{10)}$. In our experiment, a load of $25 \mathrm{gf}$ was used, which was rather heavier than the usual load.

Three types of dental stone powder, grouped by their differences in fabrication method are available in practice : dental plaster, dental stone and die stone. Dental plastcr is called $\beta$-calcium sulfate hemihydrate, and dental stone and die stone are called $\alpha$-calcium sulfate hemihydrate. According to ADA specifications, they are classified in to types III and V, while morphology classified them into dense plismlike crystals (crystacal, densite) ${ }^{8,9,11,12)}$. However, no precise classification between set dental stone and die stone is made in 
morphology. Therefore, set dental stones used for our experiments had various types of crystals, whose morphological difference could not be distinguished.

In the specimens immersed in boiling water and dried without rinsing, dental stone crystals were released on the surface due to dissolution in the outer layer, and the remaining crystals themselves were damaged; they showed stratiform or palisade structure. Crystals with hemihvdrate, which were proved by morphological study with SEM and X-ray diffraction, ${ }^{8-11)}$ might act as crystalline nucleus, around which crystals with dihydrate grew during hardening processs. However, they might be dissolved and washed out during treatment with boiling water and crystals with hemihydrate appeared on the outer layer. This picture of the remaining crystals seemed to be related to gypsum pseudomorph prepared by Uno et $a l$. by use of raw material of gypsum with dihydrate ${ }^{13)}$.

In the specimens that were rinsed after immersion in boiling water, increased surface roughness and decreased Knoop hardness in the outer layer were found. Determinations of Knoop hardness should have been made on the surface of the specimens, but they became too rough. The surfaces had to be polished to a depth of about $0.2 \mathrm{~mm}$ before measurement was possible. This meant that the true surface hardnesses could not be determined. However, this proved that effects of the immersion were not limited to the surface but also extended to the internal part of the set dental stone. Iwasaki et al. studied how the stone model was affected by prolonged immersion in $40^{\circ} \mathrm{C}$ water ${ }^{4}$. They masked half of each specimen with vinyl tape in oder to compare the exposed surface with the masked surface, and determined surface roughness. Surface roughness increased by 2-3.5 times for the first $10 \mathrm{~min}$. when washed with tap water and immersed in a container filled with water. An inspection revealed large undulations and numerous sandlike projections. Iwasaki et al. proposed that employment of supernatant gypsum slurry would be effective for the prevention of these erosions ${ }^{4}$. As to the effectiveness of gypsum slurry, Rudd et al. reported similar effects ${ }^{2}$. Habu pointed out the great effect of the application of boiling water ${ }^{3}$. He described the increase in surface roughness, the negative result of the corner reproduction test, and that the reduction of cohesive strength among pillar crystals brought on by dissolution of the crystalline surface. According to a series of studies by Mori et $a l .{ }^{8-11)}$, the rough surface was made by the remaining crystals with hemihydrate, the morphological changes of crystals with dihydrate and the disturbance of their orientation. They found the existence of hemihydrate by observation of the broken surface. In our experiment, the remaining crystals with hemihydrate seen on the surface before washing could not be detected after washing, and the crystals with dihydrate thinned as their cohesive strength weakened, leading to their projection from the surface.

\section{CONCLUSION}

The following results were obtained:

1. Surfaces of set dental stones were rougher than that of an acrylic resin plate.

2. On each specimen immersed in boiling water, highly roughened surfaces and thinner crystal bodies were observed under SEM.

3. The Knoop hardness of dental stones was considerably lowered after immersion in 
boiling water. That of die stones was about the same or lower than the dental stones. This result shows that the influence of boiling water extends not only to the surface but also inside the structures.

These results show that even a brief immersion in boiling water profoundly affects dental stone cast, resulting in rougher surfaces and lowered hardness of stone.

\section{REFERENCES}

1) Suenaga, K., Nishigawa, G., Sato, T., Matsui, K., Suzukawa, M. and Mori, H.: Linear dimentional stability and surface roughness of stone cast following immersion in disinfectant solution, $J$ Jpn Prosthodont Soc 37 (4) : 116-123, 1993. (in Japanese)

2) Rudd, K.D., Morrow, R. M., Brown, C. E., Powell, J. M. and Rahe, A. : Comparison of tap water and slurry water on gypsum casts, J Prosthet Dent 24 (3) : 563-570, 1970.

3) Habu, H.: Disinfection of stone models-Effects of scientific disinfection treatment on properties of stone models-, J J D A $\mathbf{4 5}$ (2) : 43-54, 1992. (in Japanese)

4) Iwasaki, N., Hatanaka, H., Naruse, M. and Abe, H. : Dimensional changes of stone casts after dipping, J Dent Tech. 17 (2) : 198-208, 1989. (in Japanese)

5) Nakamura, H., Fukase, Y., Kaketani, M., Nishiyama, M. and Ohashi, M.: Surface reprodaction of a dental stone model - A method for dtermining the surface roughness of a dental stone model - , $J J$ Dent Mat 6 (4) : 391-395, 1987. (in Japanese)

6) Unemori, M. : Effect of factors on the surface roughness of set dental stone, I . Relation between surface roughness and surface microstructure, J J Dent Mater 4 (3): 267-273, 1985. (in Japanese)

7) Skinner, E. W. and Gordon, C. C. : Some experiments on the surface hardness of dental stones, $J$ Prosthet Dent 6 (1) : 94-100, 1956.

8) Mori, T. and Ymane, M.: Surface microstructure and physical properties of hadened dental plaster and stone, Part 1 Crystal habit of hemihydrate crystals, J Japan Soc Dent Appar Mat 13 (26) : 1-6, 1972. (in Japanese)

9) Mori, T. and Yamane, M. : Surface microstructure and physical properties of hardened dental plaster and stone, Part II Microstructure of dihydrate crystals, J Japan Soc Dent Appar Mat 13 (28) : 200-205, 1972. (in Japanese)

10) Mori, T. and Yamane, M.: Surface microstracture and physical propeties of set dental plaster and stone, Part III Surface Microstructure and Microhardness J Japan Soc Dent Appar Mat 15 (32) : 105111, 1974. (in Japanese)

11) Mori, T. and Yamane, M. : Fractography of cast gypsum, Aust Dent 27 (1) : 30-38, 1982.

12) American dental association: Guide to dental materials and devices (8th edition), Chicago, American Dent Assoc, 104-108, 1976.

13) Uno, T.: Scanning electoron-microscopic observation of various hemihydrate crystals, Gypsumand Lime 171 : 23-27, 1981. (in Japanese) 
可否を決める重要な因子の一つであることが明らかに なった. また適切な水量は水の蒸発によっても変わるこ
とから，築盛中に変動する条件に応じて供給水量を フィードバック制御する必要があることが分かった.

\section{熱湯浸漬処理が硬質石こう模型の表面粗さおよび 表面微細構造に及ぼす影響}

鬼塚 雅, 上村典子, 梶原浩忠, 中島厚生, 末永健市

自見 忠

鹿児島大学雬学部歯科補綴学第一講座

熱湯浸漬が硬質石こう模型表面に及ぽ影響を調ぺる ために, 熱湯浸漬前後の石こう試料表面について, 表面 粗さ・ヌープ硬さの測定, および走査型電子顕微鏡の観 察を行い比較検討を行った. その結果, アクリル板に接 して硬化した石こう試料表面は, アクリル板の表面に比 べ表面粗さの増加が認められた．また SEM 像では石こ う結晶の凝集界面に多数の空吵が生じていた.これに対 して熱湯浸漬後の試料は, 明らかな面荒れが生じ, SEM
像の観察では結晶自体が細くなり,お互いの絡み合いも 弱まっていた。 ヌープ硬さは, 熱湯浸漬により著しい硬 度の低下を示した. また, 熱湯処理後の超硬質石こうと 未処理の硬質石こうとの硬度の比較では, 硬質石こうと 同程度か, あるいはそれ以下の值に低下した. 以上の結 果から，短時間の熱湯浸漬が石こう模型に大きく影響を 及ほすことがわかった。

\section{チタン鋳造床作製モデルと臨床要因：鋳型温度とスプルー条件 \\ Y. VIDOVIC, H. G. CHUNG and T. MORI \\ Biomaterials Research Unit, Faculty of Dentistry, The University of Sydney}

前回報告したチタン鋳造床作製技法を評価するための 実験モデルに, 二種の臨床要因を加えてさらに検討を加 えた. 鋳造機とこれに推奨されている埋没材の組み合わ せを鋳造システムと呼ぶことにし, 実験 1 では二室構造 鋳造機を用いる鋳造システムによる鋳型温度の影響, 実 験 2 では一室構造鋳造機を用いる鋳造システムによるス プルー条件の影響を検討した，既製の鋳造システムに第 三の埋没材を導入することの影響も検討した. 完全に鋳 造されたモデルパターンの保持孔の数により鋳造の成功 率を算出した.メーカー指定の高温鋳型 $\left(620^{\circ} \mathrm{C}\right)$ では完 全な成功率を得たが, 任意に選出した中温 $\left(350^{\circ} \mathrm{C}\right)$ と低
温 $\left(100^{\circ} \mathrm{C}\right.$ 以下) では成功率は低下した。 中温と低温では 有意な差がなく,これは第三の埋没材でも同様であった。 コバルトクロム床で一般的な $4 \mathrm{~mm}$ 直径のスプルーよ りも大きなものが有利であろうという仮定が一室構造鋳 造機システムで証明されたが, 臨床で使用するような長 いスプルー $(26 \mathrm{~mm})$ と短いスプルー $(5 \mathrm{~mm})$ との間 には有意な差がみられなかった. 第三の埋没材では 4 $\mathrm{mm}$ の直径でも高い成功率が得られ, 鋳造機の作動原理 と埋没材の組み合わせを考慮することの必要性が示唆さ れた. 